\title{
The Influence of the Protein Kinase A System in Differentiation of HL-60-Eo Cells to Eosinophils Induced by Histamine
}

\author{
Kenichi Shimada, Tomoyuki Abe, Mitsunobu Mio and Chiaki Kamei* \\ Department of Pharmacology, Faculty of Pharmaceutical Sciences, Okayama University, Okayama 700-8530, Japan
}

Received June 27, 2001 Accepted September 7, 2001

\begin{abstract}
The influence of the protein kinase A (A kinase) system in differentiation of HL-60-Eo cells to eosinophils induced by histamine was studied. Although 8-Cl-cAMP caused inhibitions of proliferation and $\left[{ }^{3} \mathrm{H}\right]$ thymidine uptake of HL-60-Eo cells similarly to histamine, no significant eosinophilic differentiation was observed. Histamine as well as 8-Cl-cAMP caused elevation of A kinase activity. However, KT5720, an inhibitor of A kinase, had no effect on histamine-induced eosinophil differentiation. $\mathrm{RI}_{\alpha}$ antisense oligodeoxynucleotide caused significant inhibition of HL-60-Eo cell growth, but $\mathrm{RII}_{\beta}$ antisense oligodeoxynucleotide had no effect. On the other hand, neither of the antisense oligodeoxynucleotides showed potentiating effects on growth inhibition induced by histamine. In addition, $\mathrm{RI}_{\alpha}$ and $\mathrm{RII}_{\beta}$ antisense oligodeoxynucleotides caused neither differentiation to eosinophils itself nor potentiation of histamine-induced differentiation. From these findings, it was concluded that A kinase is not correlated directly with differentiation of HL-60-Eo cells to eosinophils.
\end{abstract}

Keywords: Histamine, 8-Cl-cAMP, Eosinophil differentiation, HL-60-Eo, KT-5720

A subclone of HL-60 cells (HL-60-Eo cells), which preferentially differentiate to eosinophils under histamine stimulation, was obtained by long-term culture under slightly alkaline conditions $(\mathrm{pH} 7.6)(1,2)$. During the course of our investigations of the reason for the differentiation of HL-60-Eo cells to eosinophils, we found that the $\mathrm{H}_{2}$-agonist impromidine, dimaprit and 4-methylhistamine also increased the number of differentiated cells, although the $\mathrm{H}_{1}$-agonist 2-methylhistamine had no effect. The rank order of potency was histamine $>$ impromidine $>$ dimaprit $>4$-methylhistamine (3). The rank order of potency on the differentiation of HL-60-Eo cells to eosinophils was somewhat different from those observed with pharmacological effects in other tissues. For instance, impromidine is 16.8 -hold more potent than histamine in rat induction of gastric juice secretion (4). In addition, impromidine is 48.1- and 9.3-hold more potent than histamine on the guinea pig atrium and the rat uterus, respectively. On the other hand, $\mathrm{H}_{2}$ receptors are closely linked to the activation of adenylate cyclase, and their stimulation results in elevation of intracellular cAMP levels. Therefore, the present study was performed to clarify the role of the protein kinase A (A kinase) system in differentiation of

*Corresponding author. FAX: +81-86-251-7939

E-mail: kamei@pheasant.pharm.okayama-u.ac.jp
HL-60-Eo cells to eosinophils induced by histamine.

\section{MATERIALS AND METHODS}

Cells

HL-60 cells (Japanese Cancer Research Resources Bank, Tokyo) were cultured under alkaline ( $\mathrm{pH}$ 7.6) condition for 2 months. Thereafter, the cells were cultured in soft agar until the colonies became visible (HL-60-Eo cells). HL-60Eo cells were cultured in RPMI-1640 medium supplemented with $10 \%$ fetal bovine serum. In the differentiation studies, the cells were suspended in serum-free RPMI-1640 medium containing $500 \mu \mathrm{M}$ insulin, $500 \mu \mathrm{M}$ transferrin and $6 \mu \mathrm{M}$ selenious acid, and they were cultured in a $\mathrm{CO}_{2}$ incubator at $37^{\circ} \mathrm{C}$ for 6 days (2).

\section{Determination of cell proliferation}

HL-60-Eo cells $\left(1 \times 10^{5}\right.$ cells $\left./ \mathrm{ml}\right)$ were cultured in each well of 24-well plastic plates in the presence of test compounds at $37^{\circ} \mathrm{C}$ in a $\mathrm{CO}_{2}$ incubator for 6 days. Thereafter, $0.3 \%$ trypan blue was added to each well. Viable cells, visualized by the exclusion of trypan blue, were counted using a hemocytometer.

$\left[{ }^{3} H\right]$ Thymidine uptake

Aliquots of $100 \mu \mathrm{l}$ of HL-60-Eo cells $\left(1 \times 10^{5}\right.$ cells $\left./ \mathrm{ml}\right)$ 
in the medium used for the differentiation test were cultured in each well of 96-well plastic plates in the presence of test compounds at $37^{\circ} \mathrm{C}$ in a $\mathrm{CO}_{2}$ incubator for 6 days. Thereafter, $11 \mu \mathrm{l}$ of $\left[{ }^{3} \mathrm{H}\right]$ thymidine $(10 \mu \mathrm{Ci} / \mathrm{ml})$ was added to each well and incubation was continued for $4 \mathrm{~h}$. After stopping the reaction by cooling, the mixture was filtrated through a Whatman GF/C filter, and then the filter was washed 3 times each with ethanol and water. The radioactivity remaining on the filter was measured using a liquid scintillation counter (LSC-1000; Aloka, Tokyo).

\section{Determination of cell differentiation}

Morphological changes in the cells were determined microscopically after May-Grünwald-Giemsa staining. Classification of cells that showed eosinophil specific granule on smears was carried out according to the criteria reported by Tasaka et al. (2).

\section{Determination of A kinase activity}

HL-60-Eo cells were cultured in the presence of histamine or 8-Cl-cAMP dissolved in RPMI-1640 medium for a variety of incubation periods and the cells were disrupted by sonication in disruption medium $(1 \mathrm{mM}$ theophylline, $0.2 \mathrm{mM}$ EGTA, $0.2 \mathrm{mM}$ phenylmethanesulfonyl fluoride, $20 \mathrm{mM}$ 2-mercaptoethanol, 1\% bovine serum albumin, $20 \mathrm{mM}$ Tris- $\mathrm{HCl}$, pH 7.5). After centrifugation at $100,000 \times g$ for $1 \mathrm{~h}$ at $4^{\circ} \mathrm{C}, 80-\mu 1$ aliquots of the supernatant were added to mixtures containing $120 \mu 1$ of assay medium ( $400 \mu \mathrm{g} / \mathrm{ml}$ histone type II, $16.7 \mathrm{mM} \mathrm{MgCl}_{2}, 100 \mu \mathrm{M}$ ATP, $20 \mathrm{mM}$ Tris-HCl, pH 7.5) and $20 \mu \mathrm{l}$ of $\left[\gamma_{-}{ }^{32} \mathrm{P}\right] \mathrm{ATP}$ solution $(2 \mu \mathrm{Ci} / 20 \mathrm{ml}, 500 \mu \mathrm{M})$, and the resultant mixtures were incubated for $10 \mathrm{~min}$ at $37^{\circ} \mathrm{C}$ in the presence or absence of $10 \mu \mathrm{M}$ of cAMP. The reaction was terminated by addition of $20 \mu \mathrm{l}$ of ice-cold $20 \%$ TCA and the mixtures were filtrated through a Whatman $3 \mathrm{MM}$ filter. The radioactivity of phosphorylated histone remaining on the filter was determined using a liquid scintillation counter (LSC1000).

\section{Introduction of antisense oligodeoxynucleotide}

A cell suspension $\left(5 \times 10^{5}\right.$ cells $\left./ \mathrm{ml}\right)$ for cell differentiation was cultured in each well of 24-well culture plates, and $\mathrm{RI}_{\alpha}$ antisense oligodeoxynucleotide, 5'-GGC-GGTACT-GCC-AGA-CTC-CAT-3' (5), and RII $_{\beta}$ antisense oligodeoxynucleotide, 5'-CGC-CGG-GAT-CTC-GATGCT-CAT-3' (6), were added and incubated for 2 days at $37^{\circ} \mathrm{C}$ in a $\mathrm{CO}_{2}$ incubator. Thereafter, $5 \mu \mathrm{M}$ histamine and $225 \mathrm{nM}$ antisense oligodeoxynucleotide were added to the cell suspensions $\left(1 \times 10^{5}\right.$ cells $\left./ \mathrm{ml}\right)$. Two days after commencement of differentiation, antisense oligodeoxynucleotide was also added at a concentration of $225 \mathrm{nM}$ and incubation was continued under the above conditions.

\section{Chemicals}

The compounds used were obtained from the sources indicated in parentheses: RPMI-1640 medium (Nissui, Tokyo); fetal bovine serum, insulin, transferrin, selenious acid, theophylline, phenylmethanesulfonyl fluoride, KT5720 ((8R,9S,11S)-(-)-9-hydroxy-9-n-hexyloxy-carbonyl-8methyl-2,3,9,10-tetrahydro-8,11-epoxy- $1 H, 8 H, 11 H$-2,7b, 11a-triaqzadibenzo[ $a, g]$ cycloocta $[c, d, e]$ trinden-1-one), 8Cl-cAMP (Sigma Chemical Co., St. Louis, MO, USA); $\left[{ }^{3} \mathrm{H}\right]$ thymidine (Du Pont, Wilmington, DE, USA); $[\gamma-$ ${ }^{32}$ P]ATP (Amersham, Little Chalfont, UK); $\mathrm{RI}_{\alpha}$ antisense oligodeoxynucleotide, $\mathrm{RII}_{\beta}$ antisense oligodeoxynucleotide (Takara, Hyogo); and histamine dihydrochloride (Wako, Osaka). Other chemicals used were of reagent grade and were purchased from commercial sources.

\section{Statistical analysis}

Data are expressed as means \pm S.E.M. One-way analysis of variance with Dunnett's test was carried out to determine the statistical significance of differences. Probability values of less than 0.05 were considered significant.

\section{RESULTS}

\section{Effects of histamine and 8-Cl-cAMP on eosinophilic prolif- eration}

8-Cl-cAMP at concentrations of 0.1 and $1 \mu \mathrm{M}$ showed no significant effect on proliferation of HL-60-Eo. However, at a concentration of $5 \mu \mathrm{M}$ it caused a significant decrease in the number of cells. Histamine at concentrations of 1 and $5 \mu \mathrm{M}$ showed a significant decrease in the number of cells. The potency of 8-Cl-cAMP in decreasing the cell number was almost the same as that of histamine (Fig. 1A).

\section{Effects of histamine and 8-Cl-cAMP on $\left[{ }^{3} \mathrm{H}\right]$ thymidine uptake}

8-Cl-cAMP at concentrations of 0.1 and $1 \mu \mathrm{M}$ showed no significant effect, but at $5 \mu \mathrm{M}$, it significantly inhibited $\left[{ }^{3} \mathrm{H}\right]$ thymidine uptake. Histamine at concentrations of 1 and $5 \mu \mathrm{M}$ caused significant inhibition of $\left[{ }^{3} \mathrm{H}\right]$ thymidine uptake (Fig. 1B).

\section{Effects of histamine and 8-Cl-cAMP on eosinophilic differ- entiation}

8-Cl-cAMP caused no increase in the number of differentiated cells even at a concentration of $5 \mu \mathrm{M}$. On the other hand, histamine at concentrations of 1 and $5 \mu \mathrm{M}$ significantly increased the number of differentiated cells (Table 1).

\section{Effects of histamine and 8-Cl-cAMP on A kinase activity}

A kinase activity increased immediately after addition of histamine $(5 \mu \mathrm{M})$ and lasted for $30 \mathrm{~min}$, and the activity 


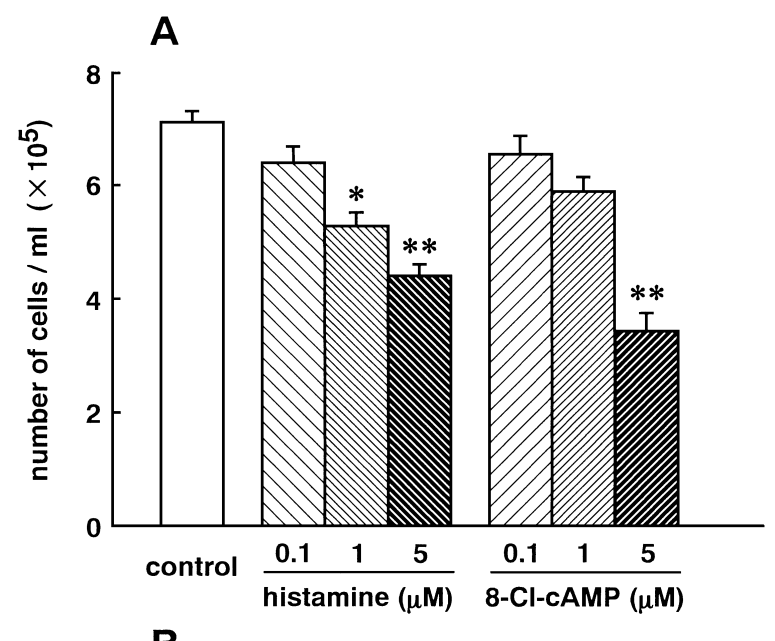

B

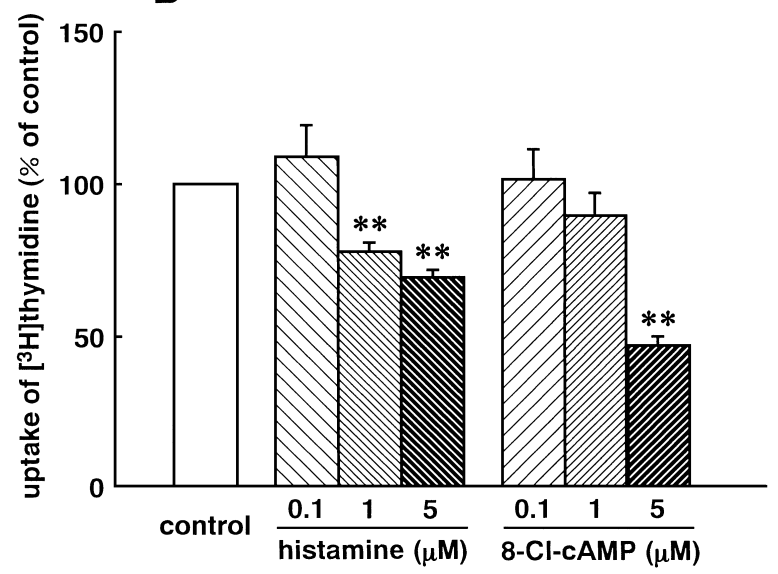

Fig. 1. Effects of histamine and 8-Cl-cAMP on eosinophilic proliferation and $\left[{ }^{3} \mathrm{H}\right]$ thymidine uptake into HL-60-Eo cells. A: Eosinophilic proliferation. The cells were stimulated with histamine or 8-Cl-cAMP and incubated for 6 days at $37^{\circ} \mathrm{C}$ in a $5 \%$ $\mathrm{CO}_{2}$ incubator. Each column represents the mean \pm S.E.M. of 5 separate experiments. $*, * *$ : Significantly different from the control $\left(P<0.05\right.$ and $P<0.01$, respectively). B: $\left.{ }^{3} \mathrm{H}\right]$ thymidine uptake. The cells $\left(1 \times 10^{5}\right.$ cells $\left./ \mathrm{ml}\right)$ were stimulated with histamine or $8-\mathrm{Cl}$ cAMP and incubated for 6 days at $37^{\circ} \mathrm{C}$ in a $5 \% \mathrm{CO}_{2}$ incubator. Each column represents the mean \pm S.E.M. of 5 separate experiments. **: Significantly different from the control $(P<0.01)$.

Table 1. Effects of histamine and 8-Cl-cAMP on eosinophilic differentiation of HL-60-Eo cells

\begin{tabular}{lc}
\hline Drugs & Differential count $(\%)$ \\
\hline Control & $9.7 \pm 1.7$ \\
Histamine $(1 \mu \mathrm{M})$ & $34.7 \pm 1.3^{* *}$ \\
Histamine $(5 \mu \mathrm{M})$ & $61.5 \pm 3.9^{* *}$ \\
8-Cl-cAMP $(5 \mu \mathrm{M})$ & $14.0 \pm 1.0$ \\
\hline
\end{tabular}

Each value represents the mean \pm S.E.M. of 5 separate experiments. **: Significantly different from the control $(P<0.01)$.

was restored to basal level after $2 \mathrm{~h}$ of histamine stimulation. Significant differences were observed after 15 and

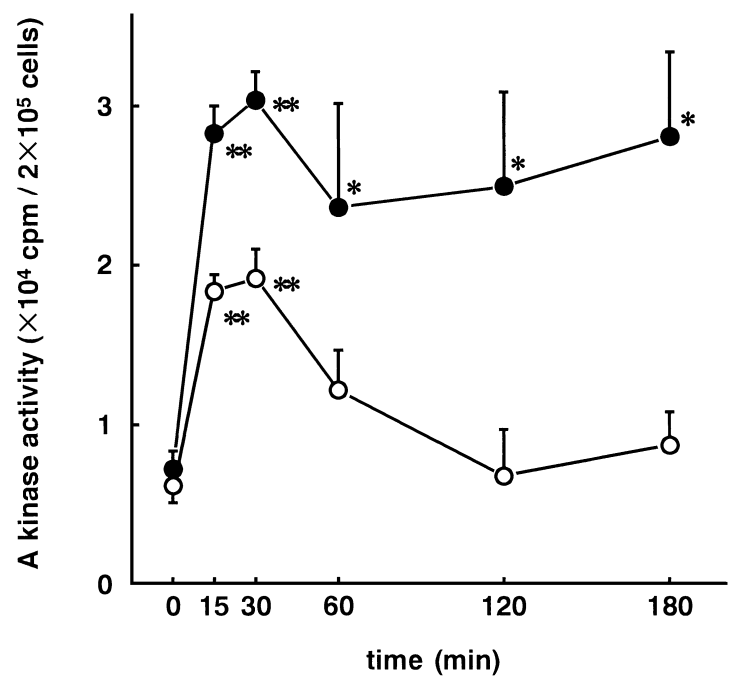

Fig. 2. Changes in protein kinase $A$ activity induced by histamine and 8-Cl-cAMP. Each point represents the mean \pm S.E.M. of 5 separate experiments. $* * *$ : Significantly different from the control $(P<0.05$ and $P<0.01$, respectively). Open circle: Histamine $(5 \mu \mathrm{M})$, closed circle: 8 -Cl-cAMP $(5 \mu \mathrm{M})$.

30 min of stimulation with histamine. 8-Cl-cAMP $(5 \mu \mathrm{M})$ also caused an increase in A kinase activity. A kinase activity was increased immediately after addition of 8-ClcAMP, and this elevated activity lasted for $3 \mathrm{~h}$ (Fig. 2).

\section{Effects of KT-5720 on histamine-induced eosinophilic dif- ferentiation}

To identify the role of A kinase in histamine-induced eosinophil differentiation, the effects of KT-5720 were studied. KT-5720 showed no effect on histamine-induced eosinophilic differentiation even at a concentration of $5 \mu \mathrm{M}$ (Fig. 3).

Effects of A kinase regulatory subunit antisense oligodeoxynucleotides on cell growth and cell differentiation

$\mathrm{RI}_{\alpha}$ antisense oligodeoxynucleotide significantly inhibited growth of HL-60-Eo cells, while $\mathrm{RII}_{\beta}$ antisense oligodeoxynucleotide had no significant effect. On the other hand, neither $\mathrm{RI}_{\alpha}$ nor $\mathrm{RII}_{\beta}$ antisense oligodeoxynucleotide influenced the inhibition of proliferation induced by histamine (Fig. 4). In the differentiation study, neither antisense oligodeoxynucleotide showed any effect on differentiation of eosinophils. In addition, $\mathrm{RI}_{\alpha}$ and $\mathrm{RII}_{\beta}$ antisense oligodeoxynucleotides showed no potentiating effect on differentiation to eosinophils induced by histamine (Table 2).

\section{DISCUSSION}

In the present study, 8-Cl-cAMP was shown to cause a significant decrease in the cell number and inhibition of 


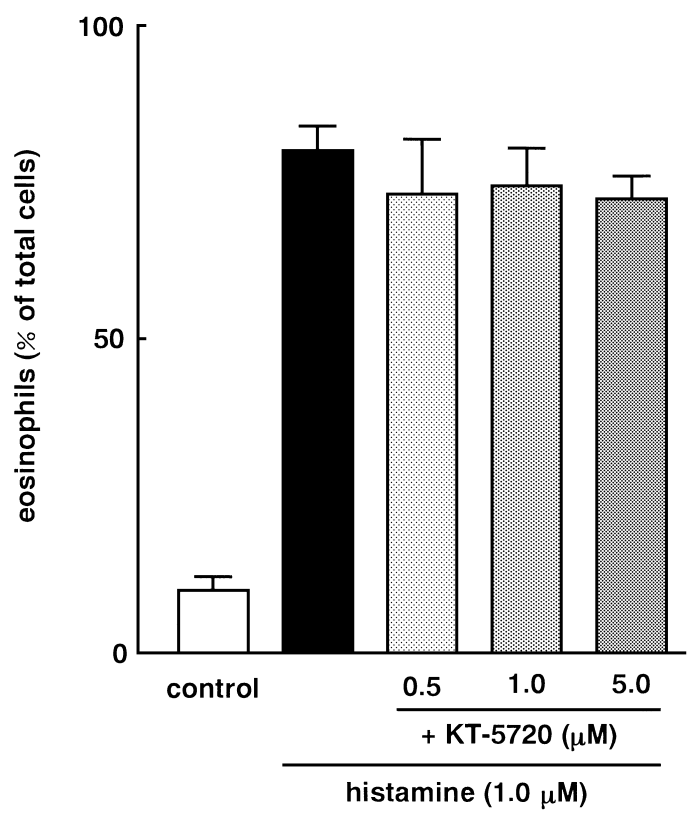

Fig. 3. Effects of KT-5720 on histamine-induced eosinophilic differentiation. Each column represents the mean \pm S.E.M. of 5 separate experiments.

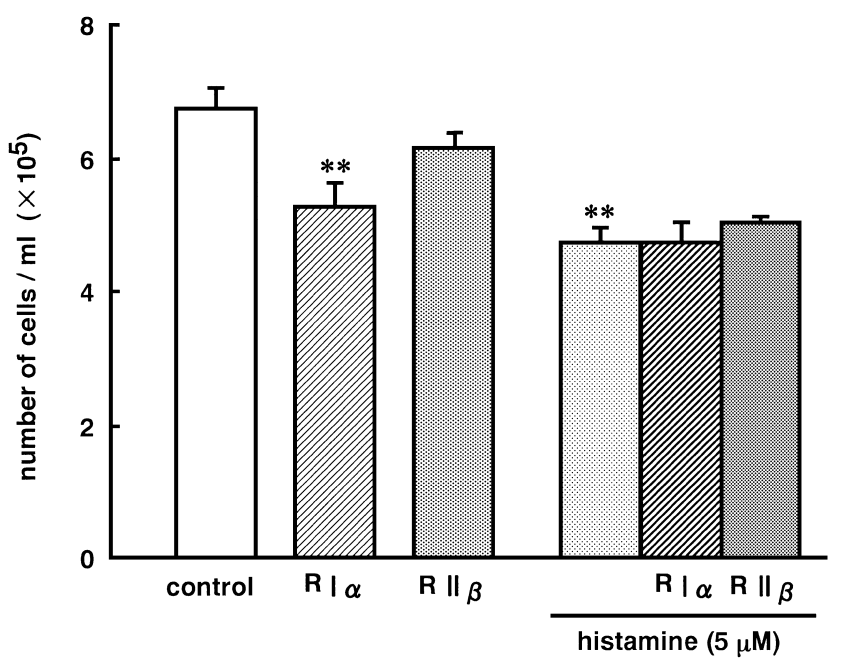

Fig. 4. Effects of protein kinase A regulatory subunit antisense oligodeoxynucleotides on growth of HL-60-Eo cells. The cells $\left(5 \times 10^{5}\right.$ cells $)$ were pretreated with antisense oligodeoxynucleotides $(450 \mathrm{nM})$ for $48 \mathrm{~h}$. Thereafter, the cells were stimulated with histamine for 6 days. Antisense oligodeoxynucleotides $(225 \mathrm{nM})$ were added at 0 and 2 day after stimulation with histamine. Each column represents the mean \pm S.E.M. of 5 separate experiments. $\mathrm{RII}_{\beta}: \mathrm{RII}_{\beta}$ antisense oligodeoxynucleotide. **: Significantly different from the control $(P<0.01)$.

$\left[{ }^{3} \mathrm{H}\right]$ thymidine uptake in HL-60-Eo cells. The effect of 8Cl-cAMP $(5 \mu \mathrm{M})$ was almost the same as that of histamine stimulation. Yokozaki et al. (7) reported that 8-Cl-cAMP caused growth inhibition of HL-60 cells. They found that
Table 2. Effects of protein kinase A regulatory subunit antisense oligodeoxynucleotides on histamine-induced differentiation of HL60-Eo cells

\begin{tabular}{lc}
\hline \multirow{2}{*}{ Drugs } & Differential count (\%) \\
\cline { 2 - 2 } & Eosinophil \\
\hline Control & $13.0 \pm 1.2$ \\
Histamine & $52.0 \pm 1.5^{*}$ \\
$\mathrm{RI}_{\alpha}$ & $14.7 \pm 3.2$ \\
$\mathrm{RII}_{\beta}$ & $11.7 \pm 2.2$ \\
$\mathrm{RI}_{\alpha}+$ histamine & $25.3 \pm 1.2$ \\
$\mathrm{RII}_{\beta}+$ histamine & $31.7 \pm 3.5$ \\
\hline
\end{tabular}

Each value represents the mean \pm S.E.M. obtained from 3 separate experiments. *: Significantly different from the control $(P<0.05)$. $\mathrm{RI}_{\alpha}: \mathrm{RI}_{\alpha}$ antisense oligodeoxynucleotide. $\mathrm{RII}_{\beta}: \mathrm{RII}_{\beta}$ antisense oligodeoxynucleotide.

$\mathrm{IC}_{50}$ of 8-Cl-cAMP on growth inhibition of HL-60 cells was $0.4 \mu \mathrm{M}$. On the other hand, in the present study the $\mathrm{IC}_{50}$ of 8-Cl-cAMP on cell growth inhibition in HL-60-Eo cells was about $5 \mu \mathrm{M}$. The difference between Yokozaki et al.'s finding and our present study may be attributable to the difference of the cell number and proliferation ability of cells used in the experiment.

On the other hand, histamine at concentrations of 1 and $5 \mu \mathrm{M}$ caused significant differentiation of HL-60-Eo cells to eosinophils. We also found that the $\mathrm{H}_{2}$-agonists impromidine and 4-methylhistamine also induced differentiation of HL-60-Eo cells to eosinophils (3). Nonaka et al. (8) reported that histamine induced differentiation of HL-60 cells to neutrophils under acidic conditions, and this differentiation was inhibited by $\mathrm{H}_{2}$-antagonists such as cimetidine, ranitidine and famotidine. These findings suggested that differentiation of HL-60-Eo cells or HL-60 cells to eosinophils or neutrophils induced by histamine is mediated by $\mathrm{H}_{2}$ receptors via the A kinase system. However, as shown in the present study, 8-Cl-cAMP did not induce differentiation of HL-60-Eo cells to eosinophils. Therefore, we investigated the role of A kinase in differentiation of HL-60-Eo cells to eosinophils in detail. Both histamine and 8-Cl-cAMP caused increases in A kinase activity in HL-60-Eo cells. In addition, we also found previously that histamine caused increases in cAMP levels in HL-60-Eo cells (9). These two alternations induced by histamine seemed to be almost parallel, but as described in the text, KT-5720, an inhibitor of A kinase, caused no observable effect on histamine-induced eosinophil differentiation. Therefore, A kinase may or may not be responsible for differentiation of HL-60-Eo cells to eosinophils. Seifert et al. (10) and Mitsuhashi et al. (11) reported that histamine increases cytosolic $\mathrm{Ca}^{2+}$ in HL-60 cells. Therefore, it seems likely that $\mathrm{Ca}$ may be responsible for differentiation of HL60 -Eo cells. On the other hand, there are two types of 
A kinase, type I and type II, in mammalian cells $(12,13)$. Rohlff et al. (14) reported that in HL-60 cells, A kinase type I comprised more than $90 \%$ and A kinase type II less than $10 \%$ of the total A kinase activity. These isomers of A kinase are distinguished by their different $\mathrm{R}$ subunits, RI and RII, that interact with the identical C subunit (14). Therefore, we examined the effects of A kinase regulatory subunit antisense oligodeoxynucleotides on cell growth and cell differentiation. $\mathrm{RI}_{\alpha}$ antisense oligodeoxynucleotide, which showed a slight potentiation of A kinase activity (data not shown), caused inhibition of cell growth in HL60-Eo cells (15), but $\mathrm{RII}_{\beta}$ antisense oligodeoxynucleotide had no effect on cell growth. In addition, neither $\mathrm{RI}_{\alpha}$ nor $\mathrm{RII}_{\beta}$ antisense oligodeoxynucleotides showed any potentiating effect on inhibition of proliferation induced by histamine. $\mathrm{RI}_{\alpha}$ and $\mathrm{RII}_{\beta}$ antisense oligodeoxynucleotides showed neither differentiation of eosinophils nor potentiation of histamine-induced differentiation. Tortora et al. (15) reported that $\mathrm{RI}_{\alpha}$ antisense oligodeoxynucleotide decreased proliferation of HL-60 cells. These findings are essentially the same as those of the present study using HL-60-Eo cells. From these results, it seems likely that proliferation of HL-60 cells and HL-60-Eo cells are closely related to the expression of A kinase type I.

Tortora et al. (15) also found that differentiation of HL60 cells to monocytes was also induced by $\mathrm{RI}_{\alpha}$ antisense oligodeoxynucleotide. However, in the present study, $\mathrm{RI}_{\alpha}$ antisense oligodeoxynucleotide did not induce differentiation of HL-60-Eo cells to eosinophils. In addition, $\mathrm{RI}_{\alpha}$ antisense oligodeoxynucleotide showed no potentiating effect on histamine-induced differentiation. These findings suggested that there are some differences in the mechanisms of differentiation of HL-60 cells to neutrophils and HL-60-Eo cells to eosinophils subsequent to the A kinase system.

\section{REFERENCES}

1 Fischkoff, SA, Pollak A, Gleich GJ, Testa JR, Misawa S and Reber TJ: Eosinophilic differentiation of the human promyelocytic leukemia cell line, HL-60. J Exp Med 160, 179-196 (1984)

2 Tasaka K, Tsurukai T and Mio M: Histamine-induced bi-directional differentiation of HL-60 cells towards neutrophils and eosinophils. Agents Actions 41, C106-C107 (1994)

3 Tasaka K, Tsurukai T, Shimada K, Abe T and Mio M: Histamine-induced differentiation of eosinophilic subclone of HL-60 cells. Inflamm Res 44, S76 - S77 (1995)

4 Durant GJ, Duncan WAM, Ganellin CR, Parsons ME, Blakemore
RC and Rasmussen AC: Impromidine (SK\&F 92676) is a very potent and specific agonist for histamine $\mathrm{H}_{2}$ receptors. Nature 276, 403 - 405 (1978)

5 Sandberg M, Tasken K, Oyen O, Hansson V and Jahnsen T: Molecular cloning, cDNA structure and deduced amino acid sequence for a type I regulatory subunit of cAMP-dependent protein kinase from human testis. Biochem Biophys Res Commun 149, 939 - 945 (1987)

6 Levy FO, Oyen O, Sandberg M, Tasken K, Eskild W, Hansson $\mathrm{V}$ and Jahnsen T: Molecular cloning, complementary deoxyribonucleic acid structure and predicted full-length amino acid sequence of the hormone-inducible regulatory subunit of 3'-5'cyclic adenosine monophosphate-dependent protein kinase from human testis. Mol Endocrinol 2, 1364 - 1373 (1988)

7 Yokozaki H, Tortora G, Pepe S, Maronde E, Genieser H-G, Jastorff B and Cho-Chung YS: Unhydrolyzable analogues of adenosine $3^{\prime}: 5^{\prime}$-mono phosphate demonstrating growth inhibition and differentiation in human cancer cells. Cancer Res 52, $2504-2508$ (1992)

8 Nonaka T, Mio M, Doi M and Tasaka K: Histamine-induced differentiation of HL-60 cells: The role of cAMP and protein kinase A. Biochem Pharmacol 44, 1115 - 1121 (1992)

9 Abe T, Shimada K, Akura H, Mio M, Tasaka K and Kamei C: Role of cAMP on the histamine-induced differentiation of HL60-Eo. Jpn J Pharmacol 67, Suppl I, 243P (1995)

10 Seifert R, Höer A, Schwaner I and Buschaner A: Histamine increases cytosolic $\mathrm{Ca}^{2+}$ in HL-60 promyelocytes predominantly via $\mathrm{H}_{2}$ receptors with an unique agonist/antagonist profile and induces functional differentiation. Mol Pharmacol 42, 235 - 241 (1992)

11 Mitsuhashi M, Mitsuhashi T and Payan DG: Multiple signaling pathways of histamine $\mathrm{H}_{2}$ receptors. Identification of an $\mathrm{H}_{2}$ receptor-dependent $\mathrm{Ca}^{2+}$ mobilization pathway in human HL-60 promyelocytic leukemia cells. J Biol Chem 264, 18356-18362 (1989)

12 Corbin JD, Keely SL and Park CR: The distribution and dissociation of cyclic adenosine 3':5'-monophosphate-dependent protein kinases in adipose, cardiac, and other tissues. J Biol Chem 250, 218 - 225 (1975)

13 Hofmann F, Beavo JA, Bechtel PJ and Krebs EG: Comparison of adenosine 3':5'-monophosphate-dependent protein kinases from rabbit skeletal and bovine heart muscle. J Biol Chem 250, 7795 - 7801 (1975)

14 Rohlff C, Clair T and Cho-Chung YS: 8-Cl-cAMP induces truncation and down-regulation of the $\mathrm{RI}_{\alpha}$ subunit and upregulation of the $\mathrm{RII}_{\beta}$ subunit of cAMP-dependent protein kinase leading to type II holoenzyme-dependent growth inhibition and differentiation of HL-60 leukemia cells. J Biol Chem 268, $5774-5782$ (1993)

15 Tortora G, Yokozaki H, Pepe S, Clair T and Cho-Chung YS: Differentiation of HL-60 leukemia by type I regulatory subunit antisense oligodeoxynucleotide of cAMP-dependent protein kinase. Proc Natl Acad Sci USA 88, 2011 - 2015 (1991) 